\title{
CRISIS, COMMUNITY, AND CONSENT IN WATER POLITICS*
}

\author{
HeNRY C. Hart
}

This is a time, as this symposium shows, when many of us can be drawn into a re-examination of our approach to the government of water resources. To a remarkable degree, there is agreement that present law and administration are defective. Among authoritative commission reports, moreover, there is considerable agreement upon the basic nature of the defects. These criticisms go to the heart of our constitutional system: to the principles that executive and legislative powers be not combined in the same hands, and that the United States concern itself with national affairs, reserving more limited concerns to the states.

Out of this accord have grown the following current recommendations-and even here, there is agreement on the first and second, and controversy only on the third: First, the President must gain the power over federal water resources developments that he has over other federal programs, especially the power to make proposals to Congress and the public on behalf of the executive branch. Second, the states and local government units, in so far as they are able, must carry the cost of water resources developments that have state or local consequences, and they must share correspondingly in policy-making. We know, third, that controlling and using the water in each drainage basin must be given unified direction, though we have not quite determined whether the direction should be departmental or regionally semiautonomous.

The self-scrutinizing mood stems not from this minor difference, however, but rather from the stubborn fact that such thorough and influential agreement has produced only trifling and peripheral action. The justification for some sense of frustration can be put with simple force by reading a few words from an earlier analysis: ${ }^{1}$

Inquiry into the condition of the Mississippi and its principal tributaries reveals very many instances of the utter waste caused by the methods which have hitherto obtained for the so-called "improvement" of navigation....

Such short-sighted, vacillating, and futile methods are accompanied by decreasing water-borne commerce and increasing traffic congestion on land, by increasing floods, and by the waste of public money. The remedy lies in abandoning the methods which have

* The author is indebted to Professor John M. Gaus, of Harvard University, for some of the ideas expressed in this article.

+ A.B. 1936, Vanderbilt University; Ph.D. I950, University of Wisconsin. Associate Professor of Political Science, University of Wisconsin. Personnel Staff, Tennessee Valley Authority, 1936-43. Author, New India's Rivers (r956), The DArk Missouri (I957).

${ }^{1}$ Theodore Roosevelt, Eighth Annual Message to Congress, in I7 The Works of Theodore Roosevelt 6I6-I7 (Memorial ed. I925). 
so signally failed and adopting new ones in keeping with the needs and demands of our people.

In a report on a measure introduced at the first session of the present Congress, the Secretary of War said: "The chief defect in the methods hitherto pursued lies in the absence of executive authority for originating comprehensive plans covering the country or natural divisions thereof." In this opinion I heartily concur,... The military engineers have undoubtedly done efficient work in actual construction, but they are necessarily unsuited by their training and traditions to take the broad view, and to gather and transmit to the Congress the commercial and industrial information and forecasts upon which waterway improvement must always so largely rest. Furthermore, they have failed to grasp the great underlying fact that every stream is a unit from its source to its mouth, and that all its uses are interdependent. ... A physician who disbelieved in vaccination would not be the right man to handle an epidemic of smallpox.

When one realizes that the source of this forthright indictment was the President, and the date $I 908$, one is entitled to a pessimistic view of the value of seeking change by calling attention to the defects.

Since 1950, however, we have begun to get help in understanding the reasons underlying the frustration of reform. Arthur Maass has made the principal contribution. $^{2}$ Such proposals as that of the first Hoover Commission, he points out, confront not merely error, but entrenched political power. The Corps of Engineers looks for authoritative instructions to the Public Works Committees and Appropriations Subcommittees of the House of Representatives and Senate, which interlock with powerful pressure groups-“the lobby that can't be licked." By comparison, it has but a formal responsibility to the President, whose very authority to reorganize the executive branch has, indeed, been conditioned by Congress upon the perpetuation of this congressional dominion over rivers and harbors. Professor Maass further observes that it is the President who has sought executive unity and broadly-oriented planning, and the vested congressional interest in direct access to local public works that has constituted the stumbling block. ${ }^{3}$

This situation may disconcert proponents of reform, since a tug of war between President and Congress promises further deadlock; but like all worth-while hypotheses, it provokes further questions. The first is the comparative one: Why, in as much as Congress has empowered the President or executive departments to select localized works for investment of federal funds (e.g., military installations, highways, hospitals, schools, and airports), should it have established so firm a hold on the civil works of the Army? The second is the differential one: In what circumstances has Congress, in fact, been willing to empower and support executive planning of water resources developments, and in what circumstances not?

These questions, together with a further curiosity as to the reasons why progress comes at so glacial a pace, make it worth while to examine both the method of deciding upon projects and the aggradation of power of the Corps of Engineers-not

See Maass, Congress and Water Resources, 44 Am. Pol. Scr. Rev. 576 (1950); and Arthur MaAss, Mudod Waters: The Army Engineers and the Nation's Rivers (I95I).

'Arthur Maass, Muddy Waters: The Army Engineers and the Nation's Rivers 122 (1951). 
as questions of the responsibility of an executive agency to the President or Congress, but rather as questions of the accumulation and focusing of political power out of common (although, of course, differently manifested) constituencies. The task would be foolhardy, of course, had we not lately acquired, from a host of researches in other fields of policy-making, provocative concepts of opinion formation; the locale and motivation as well as the official alliances of pressure groups; the variety of types of power which members of Congress, including committee chairmen, want and wield; the timing of the legislative process; and the effect of the different roles of the agencies, the Budget Bureau, and the President upon political decisions. Present knowledge brings us, in short, to the point where we can intelligently ask questions about the process as well as the structure of government decisions.

Such an inquiry requires information on policy-making in its social contextnot merely as interplay among bureaus, the White House, and Capitol Hill. Such studies are still rare, but we have them for rivers and projects of some diversity: the lower Mississippi, Columbia, Connecticut, Central Valley of California, Lower Colorado of Texas, Missouri, and (on certain phases) Tennessee Rivers. ${ }^{4}$ These are all, in some degree, political analyses. We have, in addition, descriptive accounts of the genesis of other river projects, including the Miami Conservancy District and Hoover Dam. 5

Hypotheses Concerning Public Interest in Water Resources Development

A. Within a drainage basin, intensity of public interest tends to vary directly with:

I. The physical and economic capacity of the drainage itself to serve the basin population at its established level of technology. Reliable water supply for domestic, industrial, or irrigation use; hydroelectric capacity; and a navigable waterway increase this capacity to the extent that they can be used and are needed. The basin's capacity is measured against the size of the drainage area. 2. The flood damage inflicted. This is a product of the height, duration, and frequency of floods, and the value of human occupance of the vulnerable floodplain.

3. The conscious participation of the population in the control or utilization of the basin's water resources. Near the positive extreme would be watershed associations (most of whose farmer-members conduct water-conserving farm operations), irrigation districts (to the extent that their participation comprehends the

- See Arthur D. Frank, The Developaent of the Federal Program of Flood Control on the Mrsstssippr Rrver (Columbia University Studies in History, Economics, and Public Law No. 323, 1930); Charles McKinley, Uncle Sam in the Pacific Northwest (1952); Willias E. Leuchtendurg, FlOOD Control Politics, The Connecticut River Valley Problem, 1927-1950 (I953); Mary Montgomery and Marion Clawson, History of Legislation and Policy formation of the Central Valley Project (1946); Comer Clay, The Lower Colorado River Authority, in EMMETTE S. REDFoRd (ED.), Public Administration and Policy Formation igi (1956); Henry C. Hart, The Därk Missouri (i957); Marion E. Ridgeway, The Missourt Basin's Pick-Sloan Plan: A Case Study in Congressional Policy Determination (Illinois Studies in the Social Sciences No. 35, 1955); C. Herman Pritchett, The Tennessee Valley Authority: A Study in Public Administration (ig43); Judson Kino, The Legislative History of Muscle Shonls (1936).

s See Arthur E. Morgan, The Miami Conservancy District (195i); C. A. Dykstra (Ed.), Colo. rado River Development and Related Problexis, i 48 annals pt. 2 (1930). 
storage and control of the water, as well as its use on farms), and hydroelectric distribution systems operated by members or municipalities (subject to the same proviso). Note the importance of reimbursement or financial support by beneficiaries as a criterion of conscious participation.

B. Commonnness of public interest concerning water resources development on the part of the population living in a drainage basin tends to vary directly with:

x. Intensity of public interest, as influenced by the factors in A. supra.

2. General social cohesion of the basin population. A basin centering on a city and roughly coterminous with its hinterland approximates the positive extreme.

3. Social cohesion between the communities or groups benefited by the development and the communities or groups dislocated or burdened. The large storage reservoir dislocating communities far upstream of its flood control, navigation, irrigation, or water supply benefits is an unfavorable case; so is diversion of water from a drainage in which it is inadequate to meet all needs.

4. The degree to which use of a water resource by one group or community facilitates use by another-e.g., construction of navigation facilities on a common waterway or exploitation of hydroelectricity where unit costs decline with volume. By contrast, community of interest is inhibited where water uses are mutually exclusive-e.g., consumption of a scarce supply by irrigation or pollution of a stream so as to render it unfit for other uses below.

C. The degree of interest in water resources development maintained by the general political constituency or public of any unit of government tends to vary with:

I. The conformity of boundaries of the unit to the drainage area or portion of the basin system which is under control. A drainage all significant parts of which are in one state and which occupies much of the state's territory (e.g., the Central Valley of California) represents the positive extreme; a small intercity or intercounty drainage in a state or a small interstate drainage in the United States approximates the negative extreme.

2. The relative importance of purposes served by the development among the purposes of the unit of government. This factor is, of course, relative to the capacity of the drainage as in A. supra.

Such a schematic outline of hypotheses can have meaning only as a basis for comparing particular basins and projects. Even so, some trends with regard to the relationship of its factors have been characteristic enough of the United States as a whole to be mentioned in general terms.

Most formative has been the introduction of the large multiple-purpose storage reservoir. It so dramatically increased drainage capacities for economic use (A. I.) as to bring the whole problem into national prominence in a mere decade (r935-45), featuring the completion of Hoover, Norris, Fontana, Shasta, Friant, Bonneville, Grand Coulee, Fort Peck, Tygart, Denison, and Marshall Ford Dams. But it has 
characteristically to be located a great distance, generally hundreds of miles, above the incidence of its major benefits, which have reached perhaps overlapping, but never coterminous, areas (power to farms and cities around the dam, without regard to drainage lines; irrigation to farm land way from the drainage below; and navigation and flood control to cities on the drainage below). The very engineering scope and variety of economic benefits which have captured attention, before, have also strained the commonness of interest of the vastly enlarged populations affected (B. 2., B. 3.).

Let us examine the meaning of this trend for the governmental factor (C. I.). Political units (nations, states, counties, and cities) bear only the most coincidental relation to basin units. As long as the minimum segment of the basin for engineering treatment was small, projects could be parceled among county levee and drainage districts, municipal water supply systems, and hydroelectric plants, thus fitting existing governmental boundaries. The big reservoirs to control whole basins, however, have raised a new problem: The dilemma is whether to (a) create a special governmental district fitting the basin (either by joining of the units comprising parts of the basin or by subdivision of a unit comprehending it all); or (b) handle water resources development as a part of the normal legislative and administrative tasks of a unit of government necessarily much larger than the basin involved. There are obvious constitutional and political reasons why solution (a) has been employed more within states, and solution (b) more among states. But, quite apart from the considerations of relative fiscal capacity, constitutional powers, and technical and managerial abilities, which happened to operate in behalf of federal assumption of water resources development responsibilities in the very decade of the 1930's when engineering techniques were being enlarged, we can detect a more intrinsic cause for gravitation of decisions to the larger government unit. It is the tendency we have noted for the scope of engineering and economic uses to reach beyond the capacity of affected populations to identify their common interests. But, of course, the ássumption of water resources development duties by a government unit so very much larger than each basin concerned, as is the United States, raises to critical prominence factor C. 2. How can the American public be seriously interested in the development of even such a great river as the Columbia or the Missouri, much less the Tennessee?

At this point, we reach the particular question of public interest which this article explores. It arises from the two essentially different types of consequences which a drainage may have for the people in its basin. One type has to be foreseen and planned for; it requires work not only of engineering, but investment and economic organization; it can arise, in short, only from deliberate decisions of the people. The capacity of a drainage to create consequences of this type we have outlined as variable A. $x$. But a drainage may also affect people, and drastically, without their intentindeed, because of their lack of foreknowledge. This is the flood capacity (A. 2.).

As long as floodplain occupance was generally agricultural, or of modest value, 
the consequences of floods were serious only where they occurred often. And as long as flood-control engineering was local (levees), floods might be episodic, but flood control was perennial and participative (A. 3.), not unlike irrigation or distribution of electricity; people often carried on, and always paid for, their own flood-control programs. The large multiple-purpose storage reservoir, however, has changed things. It has raised the possibility, at least, of nonparticipative flood control. In capturing hydroelectricity as a paying partner, it has enhanced opportunities for organizing a participating public; but by storing floods far from the site of the flood risk and using them for paying purposes, it has raised the possibility that people may get flood protection without organizing or financing it, save through their federal taxes. Couple this with the simultaneous trend toward assumption of water resources development responsibility by the United States, so much larger than the basins developed, and we have the ingredients of the particular hypothesis explored in this article. In our list of hypotheses, it stands as an alternative to factor C. 2.:

As water resources development decisions come onto the agenda of a government unit whose constituency has little participation in the development, public interest will be found in the contribution of the development to important purposes of the government or (alternatively) in the gravity of the crises which floods create in the absence of participative controls.

The Legislative Recorp

National catastrophes have led to insistent demands for national action, and the timing of the legislative process has been set by the tempo of destructive floods. ${ }^{6}$

Such a hypothesis can be taken as an adequate segment of the organization of our knowledge in this field only in so far as it gives meaning to the experiences investigated by various researchers. We can, however, immediately submit it to a rough-and-ready test: Does it explain the actual decisions for and against policies within the area of its purview-viz. federal adaptation to complex or multiplepurpose water resources control possibilities during the period since crisis-oriented programs came onto the federal agenda (roughly, this century)? The President's Water Resources Policy Commission has left us with a convenient abstract of the principal federal policy decisions on questions of comprehensive water resources development in its volume Water Resources Law, and we shall deal with all acts and resolutions of Congress $1903-5^{\circ}$ headnoted there. To test circumstantially whether they were reactions to crisis situations, let us collate them with the graph of annual nation-wide flood damage (adjusted to $195^{0-5}$ I dollars and to the $195^{0-5}$ value of property exposed to risk).

${ }^{\circ}$ Gilbert F. White, Human Adjustaient to Floods 24 (1945).

73 President's Water Resources Policy Comm'n, Report 383-429 (I950). 
Corncidence of Water Policy Decisions with Annual Flood Damage, IN Dollars, I903-5I

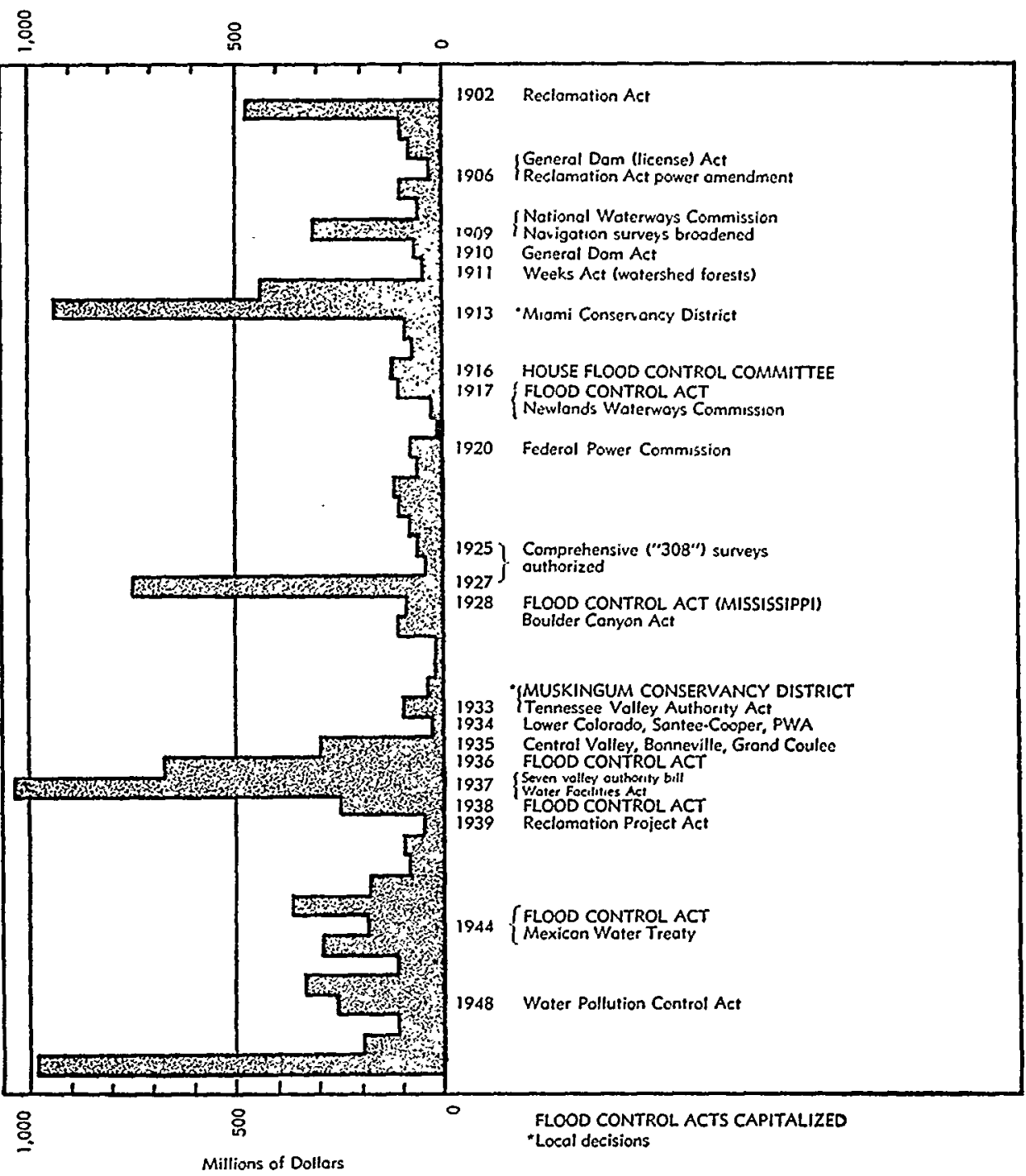

Groph from HOYT and LANGBEIN, FLOOOS (1955)

The first great flood year of the century, $1903,{ }^{8}$ brought no legislative response. Floods were still "acts of God." The second, 1909, coincided with Theodore Roosevelt's conservation crusade. In a regular Rivers and Harbors Act, Congress created its own National Waterways Commission ${ }^{9}$ and broadened the purposes for which rivers and harbors surveys were to be made. ${ }^{10}$ These preparatory steps toward

${ }^{8}$ Floods are characterized in the following paragraphs according to the chronological trcatment in William G. Hoyt and Walter B. Langbein, Floods 347-4ti (1955).

${ }^{3} 35$ Stat. 818 (Ig09).

${ }^{10}$ Id. at 822 . 
comprehensive policy were taken on executive initiative but with powerful leadership in Congress. A serious flood in rgr 3 stimulated the local flood-control program in the Miami Valley of Ohio, but it brought no national legislative response.

The year Igr6 brought a major flood to the lower Mississippi, and San Diego was cut off for a month in California floods. The House of Representatives reacted at once by creating its Committee on Flood Control. ${ }^{11}$ A few months later, Congress authorized the nation's first outright flood-control projects. Forty-five million dollars could be spent on the Mississippi and $\$ 5,600,000$ on the Sacramento. State and local contributions, in addition to levee and reservoir lands, however, had to match the federal contribution for the Sacramento and amount to half of it for the Mississippi. Future flood-control surveys were required to define the precise federal share as well as to comprehend other water uses. But flood control was also absorbed into existing rivers and harbors law. ${ }^{12}$

Simultaneously, the rgr6 floods evoked quite a different response in Congress: inclusion in the Rivers and Harbors Act of the reform that Senator Newlands had been urging for ten years-the creation of a Waterways Commission ${ }^{13}$

... to bring into coordination and cooperation the engineering, scientific, and constructive services, bureaus, boards, and commissions ... to formulate and report to Congress ... a comprehensive plan or plans for the development of waterways and the water resources of the United States for the purposes of navigation and for every useful purpose. . . .

The Commission was charged, in addition, with defining the respective federal and state or local shares of proposed projects. But Senator Newlands' language was revised, before the Senate voted, to read: ${ }^{14}$

Nothing herein contained shall be construed to delay, prevent, or interfere with the completion of any survey, investigation, project, or work herein or heretofore [or hereafter] adopted or authorized ....

Only eight years after its initial victories, therefore, the congressional effort to plan comprehensive development had its first direct encounter with the impetuosity of crisis politics, and lost. The Waterways Commission was never appointed.

The next departure in flood-crisis policy was taken in the Flood Control Act of I928. ${ }^{15}$ We have a full study of its background. ${ }^{16}$ The Mississippi River flood of r927 destroyed $\$ 300,000,000$ worth of property and killed $3^{\text {I3 } 3}$ people. Secretary of Commerce Hoover, who directed relief and rehabilitation, called it "the greatest disaster of peace times in our history."17 For the first time, the whole American people, listening to the radio and watching the newsreels, witnessed such a catastrophe in action. ${ }^{18}$ When it was over, Congress responded to the tide of national sympathy via the Flood Control Act of 1928 . There was a vigorous debate upon the policy of

\footnotetext{
${ }^{11} 53$ Cong. Rec. 2338, 2406 (rgi6). ${ }^{22} 39$ Stat. 948 (1917).

1840 STAT. 269 (I917).

I* See 3 Prestdent's Water Resources Policy Comm's, op. cit. supra note 7, at 404-05.

${ }^{10} 45$ STAT. 534, 33 U.S.C. $\$ \$ 702-702 \mathrm{~m}$ (1952).

${ }^{18}$ Frank, op. cit. supra note 4 , c. 9.

${ }^{1 \tau}$ Id. at 192.

${ }^{18}$ Id. at $179-80$.
} 
local contributions established in $1977 ;^{10}$ but how were the local levee districts along the Mississippi, already $\$ 8 \mathrm{rg}, 000,000$ in debt, ${ }^{20}$ to contribute to rebuilding their broken levees? Congress resolved the dilemma in language so thoroughly characteristic of crisis legislation that it is worth examining almost in full: ${ }^{21}$

That it is hereby declared to be the sense of Congress that the principle of local contribution toward the cost of flood control work, which has been incorporated in all previous national legislation on the subject, is sound, as recognizing the special interest of the local population in its own protection, and as a means of preventing inordinate requests for unjustified items of work having no material national interest. As a full compliance with this principle in view of the great expenditure estimated at approximately \$292,000,000, heretofore made by the local interests in alluvial valley of the Mississippi River .... in view of the extent of national concern in the control of these floods, ... and in view of the gigantic scale of the project, involving flood waters of a volume and flowing from a drainage area largely outside the states most affected, and far exceeding those of any river in the United States, no local contribution to the project herein adopted is required.

Policy to fit a sectional crisis becomes national, however, and in 1929 , Congress refunded California's contributions of $\$ 4,300,000$ to the Sacramento project. ${ }^{22}$

It is interesting to note that the engineering and cost-sharing proposals of the Chief of Engineers, General Jadwin, had reflected the position of President Coolidge in minimizing federal costs and allocating more of the burden to the area involved. ${ }^{23}$ As it first tackled the flood problem, the Corps, like Congress, searched for the national interest. And Congress left to the President final decision between the Jadwin plan and a rival engineering proposal. ${ }^{24}$ The Corps, at the top, was still an executive agency.

Extraordinary pressures for federal action were again brought to bear in the three years beginning with r935. First came a flash flood on the Republican River in Nebraska and Kansas, drowning rio people. Austin, too, was badly hurt by the Colorado River of Texas, and New York State had an unprecedented flood centering at Cortland. In the following spring, 1936, widespread March floods did $\$ 200,000,000$ worth of damages from Maine to Ohio. Then, in June I936, Congress passed the nation's first "omnibus" flood control act. ${ }^{25}$ It contained, in its initial policy statement, these remarkable words:

... the Federal Government should improve or participate in the improvement of navigable waters or their tributaries, including the watersheds thereof, for flood control purposes if the benefits to whomsoever they may accrue are in excess of the estimated cost, and if the lives and social security of people are otherwise adversely affected.

It authorized the Corps of Engineers to build $\$ 310,000,000$ worth of projects across the nation and conduct hundreds of additional surveys. Obviously, adjustments had

\footnotetext{
${ }^{12}$ Id. at $239 . \quad{ }^{20} \mathrm{Id}$. at 237.

${ }^{21}$ Flood Control Act of I928, 45 StAT. 535, 33 U.S.C. $\$ 702 b$ (1952).

${ }^{22} 45$ STAT. I38I (I929).

${ }^{23}$ Sce Frank, op. cit. supra note 4, at 224-27.

${ }^{24}$ Flood Control Act of 1928, 45 STAT. 535.

${ }^{25}$ Flood Control Act of 1936, 49 STAT. 1570, 33 U.S.C. \$701 (1952).
} 
to be made to the programs of other departments. As to reclamation, the act merely disavowed interference; and the Department of Agriculture was given the permanent assignment of retarding waterflow and preventing soil erosion on watersheds. But no means of coordination was provided.

Once more, congressional controversy centered on a proposal that the federal government bear the whole construction cost. Senator Vandenberg warned: ${ }^{28}$

The moment we have accepted that responsibility, we have accepted it for every navigable stream in 48 States of the Union; and the human imagination can hardly encompass the total extent of the burden.

The White House took the same side; once more, the Chief of Engineers supported the President; and their views prevailed. The act required local interests to pay for land and easements as well as damage caused by construction; the lower Mississippi was, of course, still exempted.

But on an equally basic issue, the Corps of Engineers followed a congressional committee rather than the President. When the bill passed the House as an "emergency measure" in 1935, President Roosevelt assigned the Budget Bureau and the newly-created National Resources Committee to a study of the proposed projects. To this, technical representatives of the Corps agreed, but the Chief of Engineers and Secretary of War did not. Such a review, they argued, would be a waste of time because "the appropriate committees of Congress ... have already called on the [War] Department for a review of previous studies on streams suffering major losses during the recent severe floods." The Senate, thereupon, passed the omnibus bill without reference to the advice of the President; it had received the endorsement of the War Department. ${ }^{27}$

The very next year brought floods to the Ohio and middle Mississippi Valleys "greater than any known since the time of settlement."28 Millions of Americans hung on press and radio accounts of the evacuation of Louisville and the defense of Cairo, with inches to spare on its temporary floodwalls. It is not difficult to understand the viewpoint of Congress. The Flood Control Act passed only the year before had obviously provided no protection. A reason had to be ascribed, and the one closest to the surface was the delay in local contributions of reservoir lands.

The role played by the Mississippi Delta in I928 fell to the Connecticut Valley in 1938; national policy was made to fit the needs of one stricken area; and the needs of Connecticut Valley, as William Leuchtenburg convincingly shows, ${ }^{29}$ were exacting. Reservoir lands had to be taken in Vermont and New Hamsphire for the primary benefit of Hartford and other Connecticut and Massachusetts cities. The states had agreed to provide the lands for the flood-control reservoirs authorized in the 1936 act via an interstate compact. The compact they negotiated reserved the

\footnotetext{
${ }^{20}$ See 2 U.S. Comm'n on Organization of the Executtve Branch of the Government, Task Force Report on Water Resources and Power 736-37 (r955).

${ }^{27}$ Sce MaAss, op. cit. supra note 3 , at $8 \mathrm{r}-84$.

${ }^{29}$ Hoyt and Langbein, op. cit. stipra note 8 , at 384 .

${ }^{20}$ See LeUchtenburg, op. cit. supra note 4 , c. 4 .
} 
hydroelectric rights to the states. They did this with the tacit approval of the Corps of Engineers, whose role both in encouraging a compact which the President would disapprove as contrary to his power policy and in glossing over the need for reservoirs in valleys which the upstream states were unwilling to inundate, Leuchtenburg calls "inexcusable." In any event, this is a clear example of policy aimed at the immediate crisis colliding with policy to serve a firmly-held national purpose. The result: deadlock..$^{30}$

With no prospect of local contribution of reservoir lands in the Connecticut Valley, Congress, in 1938 , suddenly discarded the requirement that had been reaffirmed only in $1936 .{ }^{31}$ Land for levees still had to be provided by the locality; but land for dams, reservoirs, and channel improvement was made a federal burden-and extended retroactively to cover the earlier projects. To the vastly enlarged problem of interagency coordination raised by the authorization of several large reservoirs, the law made only two minute contributions: Authorizations (but not appropriations) to the Department of Agriculture were geared to those of the Corps of Engineers; and the Federal Power Commission was given a part in recommending hydroelectric installations. ${ }^{32}$

The Flood Control Act of I944 was the final broad policy statement by Congress in this field. ${ }^{33}$ It, too, was prompted by floods, not catastrophic this time, but coinciding with an impulse toward planning post-war public works. The floods were on the Missouri, a river linking irrigation territory to the Mississippi Valley. The act resolved the resulting conflict of uses by giving to irrigation and other consumptive uses of water, present and future, priority over navigation with respect to water arising in states west of the ninety-eighth meridian. ${ }^{34}$ But since Missouri navigation was concurrently authorized, the general policy was, once more, inapplicable to the section out of whose problem it arose.

By this time, state-federal and interagency jurisdictional disputes had become a severe threat to the survival of existing programs. They were adjusted essentially by requiring each state and other federal department to review and comment on the completed plans of the Corps of Engineers, the Bureau of Reclamation, and the Department of Agriculture. This means, politically, that each agency may evoke local support for its proposed works in return for a chance to arouse opposition to those of other agencies. A clear premium is placed on the sort of unanimity engendered by crisis, and a hindrance placed in the way of mobilization of a general interest of people in an interstate region in the process of planning.

Let us turn briefly now to the national policy decisions which grew not out of crisis, but out of protracted struggle over perennial interests. Some, like the Weeks Act, authorizing national forests "for the protection of the watersheds of navigable

${ }^{30} \mathrm{Id}$. at $535-57,65,106$.

${ }^{31}$ Flood Control Act of 1938, 52 STAT. 1215, 33 U.S.C. \$701c-1 (1952).

${ }^{32}$ Id., 52 STAT. 1225-26, 12т6, 33 U.S.C. $\$ \$ 70 \mathrm{Ib}-\mathrm{r}, 70 \mathrm{Ij}$ (1952).

${ }^{38} 58$ STAT. 887, 33 U.S.C. \$70I (I952).

st Flood Control Act of 1944,58 STAT. 889,33 U.S.C. $\$ 70$ r-1(b) (1952). 
streams," ${ }^{35}$ the Federal Power Act of 1920, defining federal powers and policy regarding hydroelectric sites and providing a commission to enforce them, ${ }^{36}$ the Water Facilities Act of $19377^{37}$ authorizing the Department of Agriculture to build ponds and wells against drought, and the Water Pollution Control Act of $1948,{ }^{38}$ were directed toward well-defined objectives. They were the products of organized interest groups and national leadership devoted to those objectives. They had been worked out by factual investigation and trial and error over several years. They contributed to United States water resources policy, but not by authorizing or modifying any multiple-purpose reservoirs. Hence, they did not have squarely to face the challenge of crisis as an alternative basis of national consent.

Two laws in the entire period, however, did: the Boulder Canyon Project $\mathrm{Act}^{39}$ and the Tennessee Valley Authority Act. ${ }^{40}$ Note, behind the contrasting auspices, the similarity of legislative decisions. Both laws authorized flood control; neither was a political response to a flood. On the contrary, both stressed vendible products -electricity, plus irrigation water in the case of Hoover Dam-and clear arrangement was made for determining the cost of these products, selling them to preferred and other customers, and collecting the money. Hoover Dam could be more nearly a business proposition, since it was to meet existing demands; ${ }^{41}$ it had to rest on an interstate compact, since it disposed of scarce water claimed by competing states. The TVA was created to develop an area whose state governments were then passive as to resources development; ${ }^{42}$ it received numerous conservation and recommendatory powers. But both laws made a clear place for states and their subdivisions in distributing electricity; both had to confine the United States Government to significant contributions to stated purposes, since they were authorized outside the log-rolling process. Thus, both laws made policy decisions that have proved durable.

The Reclamation Act of $\mathrm{x} \mathrm{O}^{43}$ and its amendments represent an intermediate case. The catastrophic drought of the decade of the r8go's aroused the public support necessary for its passage. ${ }^{44}$ But drought, unlike flood, comes on gradually enough to permit much trial and error before legislation; and drought, moreover, is perennial in part of the West. The act operated in the western states and drew not on appropriations, but on proceeds from the sale of western lands; it rested on a regional public. Almost at once, however, the reclamation fund ran dry, and the Bureau of Reclamation had to seek wider support. Amendments to the original act in I906 added hydro-

${ }^{35} 36$ STAT. 961 (I9II), I6 U.S.C. $\$ 515$ (1952).

${ }^{30} 4$ I STAT. I063, as amended, 49 STAT. 838 (I935), I6 U.S.C. \$\$791a-825r (I952).

${ }^{37} 50$ STAT. 869 , I6 U.S.C. $\$ 590$ (1952).

8862 STAT. $1 \times 55$, as amended, 33 U.S.C. $\$ \$ 466-66$ j (Supp. III, I956).

${ }^{80} 45$ STAT. 1057 (1928), as amended, 43 U.S.C. \$6rin (1952).

${ }_{40}^{40}$ SтAT. 58 (1933), as amended, I6 U.S.C. $\$ 831$ (1952).

${ }^{4 A} \mathrm{~A}$ water shortage in the Imperial Valley, plus growing demands for both water and power in the Los Angeles area. See U.S. Bureau of Reclanation, Dep't of the Interior, The Colorado Rrver $55-67$ (1946).

"See Davidson, Political Regionalism and Administrative Regionalism, 207 ANNALs 138, I4I (1940).

${ }^{43} 32$ STAT. 388 (codified in scattered sections of 43 U.S.C.).

"See George Wharton James, Recraiming the Arid West xvi (igi7). 
electricity, ${ }^{45}$ in 1939 flood control and navigation, ${ }^{46}$ and in 1946 preservation of fish and wildlife ${ }^{47}$ to the possible purposes of reclamation projects. In each case, the Secretary of the Interior was required to allocate costs to purposes so as to keep repayment responsibilities clear. But by 1944 , the Bureau was in competition with the Corps of Engineers for flood-control money, and its projects authorized in the Flood Control Act of that year, both in the Missouri and Central Valley basins, have been most criticized from the standpoint of financial responsibility.

Consider, too, the strong efforts at policy-making which failed. Theodore Roosevelt's National Conservation Commission of 1908, Congress' National Waterways Commission of I909-Ir, Senator Newlands' abortive Waterways Commission in I9I7, Franklin Roosevelt's Committee on Water Flow and National Resources Board in 1934, his National Resources Committee in 1935, and George Norris' proposal for seven regional authorities in $1937^{48}$-all were nation-wide in scope, policies of reorganization, or plans for study; none called for specific water-control works. Accordingly, put forward during or on the eve of serious floods, they could not compete for congressional support with lists of dams and levees in the stricken river valleys.

All the successful programs of water control, however, are not federal. The Miami Conservancy District in Ohio is a case of direct local reaction to a flood crisisthat of Igr3-in an enduringly successful way. Aside from remarkable personal leadership, there were two assets here: The watershed of the Miami is also, to some extent, the social and economic watershed of Dayton, Ohio, which made it more meaningful than usual for Col. Edward A. Deeds to say to the citizens of the valley, "what is good for one is good for another." could be built economically for the single purpose of flood control. Even so, the Miami Conservancy District is a monument to the keen sense of responsibility which pervades a project decided upon and paid for by the direct beneficiaries.

The point is confirmed by the contrasting experience of another Ohio valley-the Muskingum. .0 Also hurt by the rgI3 flood, the people of the Muskingum lacked an urban focus of interest and leadership. The drought of 1930, however, created a second and steadier demand for reservoirs-for industrial and municipal water supply-and, after a second flood in r933, the people finally mobilized themselves into a conservancy district. From the start, they had federal help that had been unavailable to the Miami Valley twenty years earlier-a public works grant to the Corps of Engineers to build the fourteen dams-but they undertook, as required by the Flood Control Acts of 1928 and 1936 , to furnish the reservoir sites. After

${ }^{2} 34$ STAT. $x_{17}$ (1906), 43 U.S.C. $\$ 522$ (1952).

${ }^{40} 53$ STAT. I194 (1939), 43 U.S.C. $\$ 485$ h (1952).

4760 STAT. 1080 ( 1946 ), I6 U.S.C. $\$ 662$ (1952).

${ }^{18}$ See 3 President's Water Resources Policy Comm's, op. cit. supra note 7, at 395-96, 399-400, 403-05, 413-15; Leuchtenburg, Roosevelt, Norris and the Seven Little TVA's, 14 J. Poumtrcs 418 (1952).

"Morgan, op. cit. supra note 5, at vi.

${ }^{50}$ See Luna B. Leopold and Thomas Maddock, JR., The Flood Control Controversy 143-44 (1954). 
one local assessment had been made for the purpose, however, Congress, in $193^{8}$, retroactively nationalized this responsibility, providing for reimbursement to the Muskingum Conservancy District of the local money already spent. ${ }^{51}$

Equitably distributing local and general burdens for flood storage is difficult at best-Muskingum reservoirs, for instance, contribute also to flood control on the Ohio River-but it is out of the question in the wave of national sympathy following a major flood. ${ }^{52}$ An arrangement acceptable in one basin is wiped out by its impracticality in another, where the flood strikes. No policy of intergovernmental relations, accordingly, can develop in this atmosphere..$^{53}$

Introduce the perennial economic interest of hydroelectricity, however, and intrastate districts build and operate multiple-purpose projects under a variety of conditions. Here, one illustration must stand for the experience of the Nebraska power and irrigation districts, the Santee-Cooper project in South Carolina, and a number of Texas districts. The Lower Colorado River Authority controls the drainage of a part of Texas as large as the Tennessee Valley for flood control, hydroelectricity, water supply, and irrigation. Of the $\$ 70,000,000$ cost, $\$ 26,000,000$ came from PWA and Bureau of Reclamation appropriations, plus $\$ 5,500,000$ to be repaid. Yet, with Austin as an urban nucleus, people in this valley, unlike those in the Tennessee, initiated the project. Having their Congressmen Buchanan and Mansfield in the strategic positions of chairmen of the House Committees on Appropriations and Rivers and Harbors, respectively, they secured federal money outside the nation-wide flood control bill. It was appropriated on the eve, not the aftermath, of their disastrous flood of I935; and their broad program for conservation and use of the water resources of the basin suggests that they now constitute as vigorous a basin public as the population of the Tennessee Valley. ${ }^{54}$

Even so cursory a review of twentieth-century water resources development decisions as can be gleaned from existing case studies enables us to restate our hypothesis a bit more confidently in the form of generalized conclusions and questions for further exploration:

I. From the time they came onto the national agenda for government action in I9I7, major floods have given rise to drastic departures in flood-control policy.

2. The policy shifts have been in the direction of facilitating response to crises. Since $193^{8}$, this facilitation has been complete enough so that the response to floods is now expressed directly in flood-control appropriations.

3. Crisis decision leaves no time for and makes no requirement of a measured interrelation of various water resources uses. Because assumption of responsibility for contributions, repayment, or enforcement of controls by states or local governments appears as an obstacle to swift remedial action, crisis decision undermines self-help by the population directly affected.

\footnotetext{
¿1 52 StAT. 1217 ( $x_{938)}$.

ts See White, op. cit. supra note 6 , at 22-23.

${ }^{63}$ See Hoyt and LangBein, op. cit. supra note 8, at 232.

st See Clay, supra note 4.
} 
4. As a result of the technique of multiple-purpose reservoirs and the concept of basin-wide planning, strong tension has arisen between authorizations and appropriations made on the basis of flood crises and other federal water resources programs, such as power, irrigation, and watershed protection.

5. This tension is resolved by drawing multiple-purpose programs into the orbit of crisis decision, except to the degree that (a) their purposes are of national importance, or (b) they are made the business of state or local governments or a participating basin constituency.

Before we can apply these conclusions to explain the frustration of reforms, we must, however, get a clearer view of the devices of crisis politics. Two questions, certainly, require further consideration:

x. Natural crises are always confined to particular areas. But flood-control legislation has, since 1936 , been nation-wide in coverage. By what mechanism of opinionformation, group and legislative politics, are the public of the flooded area and the national public linked?

2. Modern water-control plans are complicated judgments based on analyses of a variety of technical data gathered over long periods. How can they be made to fit crisis-generated consent?

To these questions, we now turn.

\section{III}

\section{Opinion and Group InTERests}

The power question does not grip them emotionally. Power does not leave them wet and cold. Floods do.

Congressman Herman Koppleman, $1937^{55}$

Most analyses of our water policies and our national administration of water resources programs conclude that we have not determined and protected the general national interest. But is the national interest more than a figure of speech? Rivers once occupied the forefront of the national scene as sources of energy, as arteries of national expansion and trade. ${ }^{56}$ But the themes of the folk songs and folk novels of the last century have receded to the scholarly journals and books, and it now requires great imagination to appreciate that the need to control interstate waterways was a prime mover of the Constitutional Convention, or that a transcontinental river route was the geopolitical goal of our westward exploration. ${ }^{57}$

America's river-minded epoch, in short, is over. A search through all the public opinion polls abstracted in the Public Opinion Quarterly for five years 1947-5I discloses no expression of opinion on water problems as such. Nor did reference to these problems appear in any of the published responses to such nation-wide queries as, "In the Congressional elections which will be held this year, what do you think

${ }^{85}$ LeUchtenburg, op. cit. supra note 4 , at 116.

${ }^{5 B}$ Note the prominence of the river improvement conventions 1845-75. See FRANK, op. cit. supra note 4 , at 167 .

${ }^{57}$ See Bernard DeVoto, The Course of Empire (1952). 
will be the main problem which will be discussed."58 Only regional polls taken in the West Central, Rocky Mountain, and Pacific Coast states disclosed an interest in weather, conservation, and irrigation as "important problems facing this section of the country." problems (makings ends meet, health, etc.) and, to a lesser extent, with the threat of war. Water resources matters could claim only tiny fractions of the attention of the tiny fraction (eight per cent in one highly competent recent survey) of the population who expressed any worry over any national or local issue whatever. ${ }^{80}$ There need be no great mystery, then, about the dominance of special and individual interests-congressmen, lobbies, particular agencies-over against the more general interests that speak through the parties, Congress as a whole, or presidents. With respect to water resources, general interests are asleep, to be awakened only by floods and droughts, by catastrophe.

This tendency of a public to comprehend a program of government in terms of "putting out fires" rather than preventing them is familiar as well in international relations as in the budget of a city safety program. The two distinctive characteristics of water crises, however, are first, they tend toward greater damages; and second, even as crises go, they are extremely episodic. Flood damags in 1928-5I were twice as costly, allowing for change in the value of the dollar, as in I903-27. Increased damage was apparently attributable, in almost equal measure, to greater physical volume and frequency of overflows and to the building-up of floodplain property. ${ }^{61}$ Over the period when our national water policies have solidified, then, floods have, in the popular sense, been getting worse. It is also true that floods are among the most wildly uneven of internal crises. Nation-wide fire losses averaged over twentyfive years $1927-5$ I were 2.7 times greater than flood losses. But while fire losses in any one year ranged only from $\$ 235,000,000-\$ 730,000,000$, flood losses fluctuated from a low of $\$ 3,000,000$ in I93I to a high of $\$ 1,029,000,000$ in $195{ }^{62}{ }^{62}$ That is, of course, a major reason why flood insurance has waited for government sponsorship. It is also the reason, coupled with the large areas devastated simultaneously by our worst floods, why the Red Cross spends sixty per cent of its disaster relief money on floods. ${ }^{63}$

Just why a great flood or drought so captures the attention of a nation informed by mass media is a subject on which we need investigation. Purely technical factors must play a considerable part-unlike a fire or tornado, the main river flood gives the reporters and the cameramen time to get there; it is awesomely visible to the aerial photographer. There must be more substantial reasons, too, such as the dramatic test posed by floods and droughts (along with hurricanes and earthquakes) of the morale and leadership of whole communities.

\footnotetext{
${ }^{88}$ See American Institute of Public Opinion releases of Nov. 25, 1949, March 19, 1950, and June 28, 1950.

${ }^{50}$ See 13 Pub. Opinion Q. 355, 727 (1949).

${ }^{\circ}$ See Samuel A. Stouffer, Communism, Conformity, and Civil Liberties, A Cross-Section of the Nation Speaks Its Mind 58-72 (1955).

${ }^{2}$ See Hoyt and Langbein, op. cit. supra note 8 , at 85-90.

as Id. at 107 . 
If national opinion is fascinated with water problems for several days or weeks scattered over each decade and oblivious to them the rest of the time, however, opinion in certain sections of the country is quite otherwise. Let us consider first the chronically vulnerable areas, the alluvial valley of the Mississippi or the arid and semiarid portions of the West. To both might apply the inscription at the base of Colorado's capitol dome "Here is a land where life is written in water." And the controls, whether levees or ditches, by which water is made secure for human life are too obvious to be neglected. If we dig back into the early manifestations of interest in water control in these areas, we find vigorous efforts at self-help. Preceding the ditch companies and irrigation cooperatives in the West were the levee districts along the Mississippi, beginning in ${ }^{1717}$, and other flood-vulnerable rivers. ${ }^{04}$ These institutions were chartered, if at all, by state law, self-supported by sales of water or taxes on the benefited land, and largely subject to vigorous local self-government. But with tragic consistency, these self-help works were overwhelmed by unforeseen extremes of water flow: catastrophic droughts dried the ditches, and catastrophic floods topped the levees. Then, the people from these areas, where water was life or death, turned to Washington.

Washington was mainly apathetic. But in the vulnerable areas, people were locally organized, they were accustomed to raising common funds and employing managers, they were fighting to preserve an essential security in terms of water which they felt they had earned by previous exertions. So, they set about deliberately to lobby, year in, year out, for the national protection they knew the nation would gladly extend in the season of catastrophe. "People showed much enthusiasm during and immediately after floods but they soon forgot. This phase of the problem the Mississippi Levee Association proposed to meet. ..." In Incorporated after the xyI2 flood, the Association and its tireless secretary, John A. Fox, had, by the time of the next major Mississippi flood in 19I6, done its propaganda work so well that Congress, in I9r7, put the United States into the levee business.

Without that history thus epitomized, without a concept of the interplay between an episodic national interest and a perennial interest in the areas of special vulnerability, one cannot begin to understand the national power, but sectional orientation, of "the lobby that can't be licked." The organized water interests in the deltaic valley of the Mississippi and, to a lesser extent, in the arid West had "sacred cow" status; in one form or another, they were as old as white settlement. To the nation, they said, in effect, "We did all we could to protect ourselves; our efforts were destroyed by acts of God. The nation must take up the burden for the sake of its own threatened investments (or the winning of the West)." No doubt, as the names indicate, the National Rivers and Harbors Congress, proposed in rgor by a New Orleans businessman, ${ }^{66}$ and the National Reclamation Association, proposed in 1932

'See Frank, op. cit. supra note 4, at 15 et seq.

${ }^{65} I d$. at $\mathrm{I} 69$.

${ }^{86}$ See National Rivers and Harbors Congress, Report of the Proceedings (ig01). 
by the Commissioner of Reclamation, ${ }^{67}$ were intended as genuinely national associations. But some degree of sectional bias was almost inevitable where some sections of the country had long been intensely interested and others were only recently or fleetingly so.

If we now broaden our view to take in all the subnational interests which have made themselves felt in water resources programs, we see a disconcerting variety. To go no farther, let us consider the varied bases of support of the Miami Conservancy District, the Salt Creek-Wahoo Watershed Association, the Lower Colorado River Authority, the TVA, and the Pick-Sloan plan for the Missouri. As our earlier hypotheses suggest, a number of factors influence the difficulty of mobilizing a basinwide constitutency. In an intrastate basin, such as some of the small watersheds, the Miami, or the Colorado of Texas, such a river-oriented constituency may generate itself, depending partly on the social cohesion of the drainage-area populace or the importance of water resources to them. In the difficult case of the interstate basin, however, a potent drainage may be employed by statesmanlike administration to arouse a sense of participation in so many common enterprises (navigation terminals, soil-erosion control, power distribution, waterfront planning, reservoir parks, improved labor relations, adult education, forestation, and industrial development) as to develop a lasting identification with the basin development on the part of virtually all politically active residents. This is evidently what has happened in the Tennessee Valley. ${ }^{68}$ In a different interstate situation, where the prospects of social cohesion are still lower but the state governments are highly alert to their competing claims for scarce water, a firm agreement may be reached among governments without evoking appreciable loyalty of basin people to the program as a whole. This was the circumstance of Hoover Dam.

At some point, a characteristic decision faces all complex water resources developments. The actual assumption of responsibility by local people is slow, irregular, spotty. ${ }^{69}$ At least one needed individual, group, city or state will hold out. Pressure mounts on the federal agency to assume the local burden so that its work can move ahead. To the extent that it does, local groups and local governments turn their attention to Washington. To the extent that federal policy-makers resist the pressure,

${ }^{07}$ Sec Hearings before a Subcommittee of the House Committee on Public Lands on Irrigation and Reclamation, 8oth Cong., Ist Sess. 85-86 (I947).

o8 Although there has been no adequate study of this point, the TVA's claims have been confirmed by the opinions of scholarly observers. See Ray, The Infuence of the Tennessee Valley Authority on Government in the South, 43 AM. PoL. Scr. Rev. 932 (1949); MoKrncey, op. cit. supra note 4, at 536. Professor McKinley shrewdly observes that the usual charges that the valley authority represents "an outside dictatorship" are countered by the criticism in the most exhaustive study of the question, Primip Selznick, T.V.A. ANd The Grass Roors (1949), that the TVA has yielded too much to the extension service-Farm Bureau influence in the valley. McKinley, The Valley Authority and Its Alternatives, 44 AM. Por. Scr. Rev. 6rg (1950).

${ }^{00}$ Leopold and Maddock made this diagnosis of the new watershed protection program of the Department of Agriculture in 1954. LEOpold AND MADDock, op. cit. stipra note 50, at $16 \mathrm{x}-64,2 \mathrm{r}-\mathrm{r} 4$. In 1956, congressional review of the program corroborated their conclusion. Hearings before the Subcommittee on Conservation and Credit of the House Committee on Agriculture, on Amendments to the Watershed Protection and Flood Prevention Act, $84^{\text {th }}$ Cong., 2 d Sess. (1956). 
however, demands for action focus on governments within the basin. This is the necessary, although not the sufficient, prerequisite of a basin constituency.

IV

\section{Log-Roluing and Crisis Legislation}

Compromise is the legislative way of life. It is the sacrifice of a lesser for a greater interest in order to gain a majority. Log-rolling, on the other hand, is the acceptance of matters of no interest to gain a majority for one's sole desire. In recent years, Congress has authorized the investment of federal funds in airports, housing and slum clearance, schools, hospitals, and even the military installations of the Corps of Engineers through the interplay of local and group interests. But these authorizations are always tested by important national concerns, and the compromises are, in this sense, creative. Why, then, does the sterile arithmetic of log-rolling survive for water authorizations alone?

It is true that log-rolling in this field has a history going back at least to 1826 . Albert Bushnell Hart left us a "Biography of a River and Harbor Bill"70 as of 1888 , which needs only the revision of the titles of congressional committees and the addition of two zeros to the dollar amounts to portray log-rolling in 1957. But there were influential men in Congress, Ig00-I7, who demanded a better approach. Representative Theodore Burton, who warned the initial meeting of the National Rivers and Harbors Congress against unproductive and scattered appropriations, ${ }^{71}$ and who chaired the National Waterways Commission Congress set up in 1909, was one. Senator Newlands was another, and he won congressional chartering (only on paper, as it turned out) of an even more comprehensive Waterways Commission in 1917. Senator Norris, in the I920's, exerted his leadership on Muscle Shoals, outside the sphere of water politics, in the Agriculture Committee. Since 1936, however, there have been lonely attacks on log-rolling, but no constructive leadership seeking the national interest in water policy. Log-rolling, unhappily, is more than a survival; it no longer encounters serious contest.

The significance of the omnibus bill for the Congress must be viewed with reference to the localism of individual members, the lack of general leadership, and the ephemeral crisis interest of Congress as a whole. Floods often come in the spring months, just when flood-control bills are under consideration. Each specific project has supposedly been reviewed in the projects committee of that anomalous organization, the Rivers and Harbors Congress. It comes then to the Public Works Committees of the House and Senate. No doubt, here, the long-standing concerns of men from the Mississippi Delta-the late Judge Whittington and Senator John Overton were instances-who have won disproportionate leadership during Democratic majorities by the seniority rule, receive undue consideration. Sometimes, committee leaders have occupied themselves with statements of general policy in flood-control

${ }^{70}$ Am. Hist. Ass'N PApers i8o (1888).

${ }^{71}$ National Rivers and Harbors Congress, op. cit. supra note 66, at 74-77. 
acts, but nothing is farther from their calculations than abandoning the omnibus format.

One further procedure opens congressional decisions in these matters to logrolling: the great excess of authorizations over actual starts. This means that Congress need not take too seriously the authorization or approval of a project. The Chief of Engineers has classified \$I,200,000,000 worth of authorizations as "clearly inactive."72 At the present rate of spending, twenty-two years of future work stands " authorized. ${ }^{73}$ From this long list, it is much easier to select for appropriation projects which fit the requirements of log-rolling, especially in a flood crisis; for there almost invariably are approved projects for dams and local protection works in the afflicted area, awaiting only money.

Confined to "rivers and harbors" bills, log-rolling was visibly "pork" and, hence, vulnerable. In flood crises, however, log-rolling meets the need of the moment for large-scale action. In both cases, the leadership in the legislative process tends to come from the areas of most intense interest, so that there is a sectional bias beneath nationwide lists of projects and assertions of general policy.

The alternative to this procedure most often proposed has been project authorization by the President or a department head. ${ }^{74}$ Certainly, this is the desirable form of decision upon the lesser, simpler schemes. But to state in general statutory language guides to executive decision upon complex developments of major basins is unrealistic. The critical needs for water, the potential in the drainages, the fit between basin and state boundaries, the history of federal activity, the burden on the nation's taxpayers are all too varied from basin to basin to permit regulation in the abstract. In any event, consideration of the problem of a major basin at the stage when it merits comprehensive development under federal sponsorship can elicit more truly national attention than verbal statements of policy. What is needed as an alternative to the omnibus bill, then, as is so often needed in constitutional government, is a differentiation of the major and the minor decisions.

\section{V}

\section{Crisis Agency}

To try to solve our stubborn problems of water use by administrative reorganization is, we can now see, superficial and, therefore, unlikely to succeed. For what has to be redirected essentially is the form in which public attention is focused. But that root problem is itself strongly conditioned by the present administrative organization.

Congress looks for engineering advice on all water problems to the Corps of Engineers. This is a body of 50,000 civilians and 10,000 Army officers (including 8,000 reserve officers), of whom 250 officers and 20,000 civilian employees are en-

\footnotetext{
${ }^{72}$ See 2 U.S. Comm'n on Organization of the Executive Branch of the Government, op. cit. supra note 26 , at 984 .

${ }^{73} \mathrm{I}$ id. at 39 .

7t See Maass, Congress and Water Resources, 44 AM. Pol. Scr. Rev. 576, 592 (I950).
} 
gaged on "civil functions," or water use programs; the remainder on building air bases, training Engineer troops, and other military duties. Even of the 250 officers engaged on civil public works, all but thirty-one had, in 1954, some concurrent military duties. ${ }^{75}$

Let us consider the viewpoint of a typical officer of the Corps of Engineers who is crucial as a proponent of water plans-a district or division engineer. He has the rank of colonel. Of his sixteen years of service, four or five have been spent on civil works. He has been assigned to his district (e.g., Vicksburg, Savannah, or Fort Peck) or division (e.g., lower Mississippi Valley, South Atlantic, or Missouri River) for three years. His tour of duty may, in fact, be ended in two, since rotation is considered essential to training for military administration. His command consists of only a handful of other officers, plus an average of 220 civilians in the case of a division, 850 in the case of a district, where design is done and contractors supervised. The civilians-that is, the quarter of them who are professionals or subprofessionalstend to have longer experience on the drainage in question than the officers and collectively a wider variety of professional backgrounds in specialized fields of engineering and in such ancillary fields as hydrology and transportation economics. It is the district or division engineer, however, who stands as the sole representative of the Corps and the advocate of its plans before the public, whether at meeting in the area or before congressional committees.

In his Muddy Waters, Professor Maass has documented the "shirking of responsibility" by the Corps of Engineers for decisions which might arouse local or congressional controversy. ${ }^{76}$ But from the viewpoint of a district or division engineer, it is difficult to see any alternative. "Keeping clear of politics" is a canon of professional ethics for the career Army officer. To draw the fire of a group of congressmen, or even of the influential interests of a city or state, would represent a considerable failure in this regard. But who is to decide the stubborn matters of political controversy involved in a major water resources development? The more incongruous civil functions in a military department have grown, the less have Secretaries of War, or later of Army and Defense, been inclined to pay the price of congressional warfare to take control of them. Nor has the Chief of Engineers, himself a career Army officer, been more inclined toward political controversy than his subordinate. ${ }^{77}$ So, demands of Congressmen and resistance of cities and farmer groups have all descended upon the district engineer.

"On top, not on tap," what is the expert to do? The Corps of Engineers' solution seems inevitable. They wait for "local interests" to agree among themselves, mean-

${ }^{75}$ See Sturm, Civil Functions of the Corps of Enginecrs: Relation to Military Mission, in 3 U.6. Comm'n on Organization of the Executive Branch of the Government, op. cit. stipra note 26, at $1473,1517-20$.

${ }_{76}$ MaAss, op. cit. supra note 3, c. 2 , especially p. 57.

${ }^{37}$ The situation is at the opposite extreme to that described by Gordon Clapp as characterizing the TVA. Its Board of Directors takes all congressional pressures, including those of individual congressmen, and insists that its staff make purely technical and managerial proposals. Gordon R. Clapp, THe TVA, An Approach to the Development of a Regron 39-43 (1955). 
while making no recommendation which would encounter opposition strong enough to stir Congress. Concerted opposition was and is unlikely as regards channeldeepening or local levees and floodwalls. Modern flood-control engineering, however, poses more difficult political problems. The resistance to great storage reservoirs on the part of the people dislocated does not reconcile itself with the advocacy of the benefited city-dwellers below. So, the Corps has several times "officiated at the dismemberment of its own plan for flood protection"78-for instance, by building floodways while the reservoirs on which their safety depended were balked by political opposition. So, the Corps has welcomed assumption by other agencies of all responsibility for uses of its own dams which involve the potential conflicts inherent in collection of money from users-thus, readily agreeing, for example, that the Department of Interior should market its power and, usually, distribute its irrigation water.

While the Corps of Engineers has, thus, been accused of localism and the neglect of multiple purposes, it has also come under attack from the opposite direction for favoring big storage projects at the expense of local adjustments of the floodplain. ${ }^{79}$ Politically, this is all of a piece, for the widening of clear floodways through cities, the recognition that there may occur superfloods which are uneconomic to control, the local assumption of the cost of strictly local protection, the inclusion of floodplain zoning in plans-all are solutions which would arose local resistance and thus give the district officer the appearance of a political contestant.

Now we are in a position to understand how the Corps of Engineers comes under repeated criticism by authoritative study commissions, while enjoying an increasing public esteem. For, the outcome of the shirking of responsibility to get unpopular storage built and to keep unsafe floodplains clear of buildings is the dramatic increase of flood damage which we have observed. Yet, the very catastrophe which warns the study commission of the weakness of our flood-control program creates for the Corps of Engineers officer the climate of political unanimity he needs to advance bold proposals. Remember that he can count on, at most, two or three more years of responsibility for the particular drainage. What he can accomplish in that brief span is what the victims of the current flood insist on: authorization of a plan of works designed to protect them against a recurrence of that particular flood. Whether the plan is too grandiose to be completed, whether some of its key reservoirs will be blocked by those who would be dislocated, and whether the project has a claim to priority in the nation's limited investment (to say nothing of the broader questions of most economical multiple uses) are not his crucial concerns. He is conscientious enough to worry about them, but isolated as he is from the executive hierarchy, he ascribes responsibility for them to a body which, considered as a whole, has an even shorter time perspective than his, the United States Congress.

\footnotetext{
${ }^{78}$ Leuchtenburg, op. cit. supra note 4, at ro7. See also MaAss, op. cit. supra note 3, at 53-56; HART, op. cit. supta note 4 , at $150-52$.

${ }^{70}$ See Horner, Report of the Task Group on Flood Control, in 2 U.S. CoMm's ON Organization of the Executtve Branch of The Government, op. cit. stipra note 26, at 718, 811-15.
} 
What if catastrophic floods recur after a key plan of the Corps of Engineers has been authorized and supported by appropriations as generously as Congress is ever apt to do? One cannot understand the invulnerability of the Corps's position without appreciating its flood-rescue role. Consider the incident which certainly posed the ultimate test: the Missouri basin floods of $x 95 \mathrm{r}$ and $1952{ }^{80}$ They occurred at the height of press interest in and citizen support for the forthright recommendations of the first Hoover Commission to transfer the Corps's civil functions to the Interior Department. They occurred five and six years after the Corps had been at work on its "comprehensive plan" for flood control. The Kansas City flood-up to then, the nation's most damaging-revealed not only that the district engineer's previous plans had calculated on too little water, but that he had permitted them to be dismembered by building floodwalls in Kansas City without the upstream reservoirs he knew were needed to render them safe. When catastrophic floods struck the Missouri above Kansas City the very next spring, President Truman flew to Omaha for inspection. Newspaper reports (hopefully leaked, no doubt) had it that he was about to send Congress a reorganization plan finally carrying out the Hoover Commission proposals to transfer river work from the Army. In Omaha, however, the President met the Chief of Engineers, General Lewis A. Pick, who was directing the truly heroic work of raising the Engineers' levees. The whole floodplain went under, but Omaha and Council Bluffs were, after three days of suspense, saved by inches. Nothing more was heard of any plan to take river work away from the agency that won that fight.

The Corps of Engineers has become a crisis agency. In congressional terms, fifty-six per cent of its new work receives appropriations under the heading of "flood control"; "rivers and harbors" are in second place. ${ }^{81}$ Isolated from the executive hierarchy by the very incongruity of its function in a defense department, it depends for decisions and support on Congress-on Congress not, however, as it may be challenged to define broad policy, but rather in its local and ephemeral manifestations. Likewise, it depends on the consent of "local interests"-not, however, as they might be challenged to identify their community of interests in cities and states, but rather upon the immediate common denominator of consensus. That is provided in both cases by crisis. ${ }^{82}$ Flood fighters in their rescue mission, Corps of Engineers officers are drawn by the source of their political support, as by their isolation from the broad continuing aims of civil administration, to become flood fighters in their planning, too.

${ }^{80}$ The author published an account of this episode in the Milwaukee Journal, April 27, 1952, 55, pp. I, 3.

${ }^{81}$ See 3 U.S. Comm's on Organizatton of the Executive Branch of the Government, op. cit. supra note 26 , at $1544-45$.

${ }^{82}$ It is the crisis of a serious flood which reveals the political impotence of the interagency committces. They are ignored. See McKinley, op. cit. supra note 4 , at 630 . 
Frustrated Reforms and the Future

Viewed in the perspective of the rising power of the chief executive in the American constitutional order, the history we have reviewed presents an anomaly. In the essential decisions regarding federal development of our water resources, the most important sector, flood control, has developed virtually outside executive control. This would be strange enough were it not interlocked in multiple-purpose reservoirs with other federal programs; and we have found those other programs drawn away from executive direction and into the vortex of crisis politics as often as we have found the contrary.

All the while this hiving-off has proceeded, authorities in public administration have been calling for integrated departmentalization of the executive branch in the field of water resources. If we examine the whole record of reform proposals, however, we are brought up short by the fact that fifty years have produced only compromises of the original idea. Theodore Roosevelt put it most forthrightly and with the maximum popular appeal and political effectiveness in rgo8. Herbert Hoover formally proposed merger of the Corps of Engineers in the Interior Department in 1932. ${ }^{83}$ No subsequent president has gone that far. The first Hoover Commission recommended transfer of the Corps's civil functions; but the second Hoover Commission dropped it, calling, instead, for a Water Resources Board in the Executive Office and a strengthening of the Budget Bureau to evaluate water resources development projects. ${ }^{84}$

Our analysis shows how seriously both of these latter are needed, for the crucial weakness of the executive in dealing with water plans advanced in crisis has been that he had no specific program to propose at the moment of political demand. This was known full well twenty years ago by both Franklin Roosevelt as president and the alliance of congressmen, Corps of Engineers, and the rivers and harbors lobby which dominates water resources authorizations. The President was more interested in the problem and better informed than other presidents are apt to be; moreover, his Dutch was up. But he was defeated in 1943 on precisely the two recommendations which the second Hoover Commission brought forward in $1955^{85}$

It is only from the narrow viewpoint of the specific reorganization proposal to integrate federal water agencies, however, that our record of fifty years of federal decisions warrants pessimism. Bold proposals have been made and even enacted into law; but they have never been proposals for mere reorganization. Invariably, they have been ways of capturing from our water resources some new contribution to a currently powerful demand of the American people. Reclamation was the answer to the frustration of our westward march; the various waterways commis-

${ }^{83}$ Proposed Reorganization Plan of Dec. 9, r932, 76 Cong. Rec. 234, 237 (r932).

84 See U.S. Comm'n on Organization of the Executive Branch of the Government, ReorganizaTION OF THE DEPARTMENT OF THE INTERIOR I (I949); I id., op. cit. supra note 26, at 67 .

${ }^{85}$ See MaAss, op. cit. supra note 3, at 105-08, 109. 
sions to the transportation bottleneck and the high-handedness of the railways; and Theodore Roosevelt's power policy and the Federal Power Act to the need for abundant and cheap electricity across the continent. What we are apt to miss in our preoccupation with the mechanics of government is that Franklin Roosevelt's water policies, in so far as they were successful, were, to a minor extent, measures directed against drought in the Great Plains and, to a major extent, measures to pull important and generally underdeveloped sections of the nation out of the Great Depression. That is as true of the TVA and of the state authorities launched with PWA funds as of Bonneville and Grand Coulee and Fort Peck Dams.

In a sense, then, the answer to crisis politics has, in fact, been politics alerted to the larger crises-the generally and intensely-felt needs of the nation. But the record of the past permits us to look a bit more directly at the future. It was World War I that intervened, just when Senator Newlands had won his Waterways Commission, to divert the attention of the nation and the President and leave the infant floodcontrol program to log-rolling. It was World War II that intervened at the climax of President Roosevelt's battle for executive direction of water resources planning; while the nation was preoccupied with other campaigns, he lost not only his executive staff for coordination, but, in the Flood Control Act of 1944, leadership of the crucial adjustment of reclamation with rivers and harbors work. It is time-for those who are interested in improving national water resources programs to ask candidly whether the next decade or two is not apt to present crises more like those of the war periods than those of the westward expansion, the development of our public utilities, or the Great Depression.

If one assumes that the political questions of first importance for the national public will be, as opinion polls indicate they are now, questions of war and peace, some national interest in water resources may, nonetheless, be emerging on a second level of importance. One cluster concerns water in agriculture. Certainly, reclamation must give way to irrigation as a technique of cultivation and, thus, win nationwide importance. Certainly, we are accepting control of the loss of topsoil as an aspect of flood control worth national support. Sooner or later, we must also deal with the moisture situation on the Great Plains.

Another cluster of growing water problems is essentially urban and industrial: Water supply will soon limit our industrial development, as it already limits industrial location. More cities will run short of water. Pollution is a growing national problem. We have stumbled almost blindly into a policy of national flood insurance. Floods will continue to inflict greater damage to our cities; and we shall have to decide sooner-or later whether we wish to control the damages or merely invest billions in a doomed effort to restrict rivers to a smaller and smaller part of their floodplains. Flood insurance, if we mean it, will force that decision very rapidly.

However uncomfortable it is for a generation stirred by "one river, one problem," we are face to face with the fact that each growing meaning of our water resources is in terms of a purpose going far beyond water control. We must think of naviga- 
tion as transport, of hydroelectricity in a system of fuel (including atomic fuel)generated power, or flood control as city planning, of irrigation and watershed treatment as agriculture, and so on. This development is not new or strange as our economy grows in complexity. It would not be surprising had we not needed to generate so much fervor first for conservation and then for unified water resources development in promotion of sorely needed reforms, as to forget that these are not purposes, but techniques to be employed to meet one or more needs of our population.

How these needs might be interrelated and dramatized so that they might attain national prominence is beyond the scope of this article, although my own grouping inclines toward water for agriculture and water for urban growth. But the first conclusion of this article can stand, regardless of the particular overriding needs toward which we may point our water resources programs. It is that unless we aim our policy and organization at some need which is of known importance to the American people, we shall continue to be frustrated. That is true not only because the vested agencies, committees, and interest groups are too strong to be dislodged for the sake of administrative neatness, although that is true enough. It is true because the most likely outcome of a crusade for unified organization of national water resources programs, in the absence of any popular purpose, is their unification in the crisis agency which has the eye of the nation on the only occasions when the nation is now genuinely concerned with water. The first Hoover Commission failed to take civil functions from the Army in 1949; the second Hoover Commission proposed giving the construction of Soil Conservation Service headwater dams to the Army in $1955 .^{86}$

None of this argument is directed against the need for single control of the water of a drainage basin or single direction of the complex process of survey, design, and advocacy by which such single control can be made to produce the fullest human values. Our analysis has been premised on this need. But we are driven by that analysis to question whether unification of either variety can be effected, short of executive fiat, in the interest of administrative efficiency per se. Presidents themselves, however concerned with the span of control, have responded rather to the potential political demands to which they might give leadership. These have called not for administrative simplicity, but for visibly new (and, hence, usually separate) services-forestation, irrigation, and public power. Or they have called for the dramatic regeneration of a portion of the nation-the valley authority fit the demand. There is no assurance-in fact, little likelihood-that these will be the potential national demands of the future; and we must be alert for the new ones by which alone successful organizational change can be energized. But there is even less likelihood that the American people, awakening to their responsibilities for world leader-

so I U.S. Comm'n on Organization of the Executive Branch of the Government, op. cit. supra note 26 , at 190 et seq. 
ship, will accept as a problem for decision the executive organization or procedure for deciding on water resources developments.

Increased participation in water resources development by states and their subdivisions is the second recommendation upon which authoritative commissions agree. $^{87}$ This recommendation is the only basically new one since Theodore Roosevelt. Two strong new arguments can be made for it: First, is the point stressed above, that policy-making for the nation as a whole is preoccupied with larger issues and that water resources development plans tend to get considered without benefit of general public scrutiny if they are decided in Washington in any detail. Second, is that states and cities have now demonstrated new proficiency in making water policy and administering water resources. ${ }^{88}$ The best of them have certainly surpassed the United States in clarifying their water law and possibly in organizing their administration of water resources programs.

Increased state and local participation, moreover, is being put into practice. But there's the rub. "Partnership," in actuality, has meant the withdrawal of the United States Government from hydroelectric development, however large-scale, while it remains in the business of building levees and floodwalls, straightening channels, and deepening harbors, however minute. There could be no more telling, because inadvertent, demonstration that in the absence of national political purpose, the controversial aspects of water resources policy are neglected, that those supported by the fleeting and aimless unanimity born of crisis supervene.

But assuming an attempt to free the national government from all sorts of water resources responsibilities which clearly benefit states or localities and fall within their capabilities, it is clear that progress cannot be made by treating the whole country uniformly. That is true for two reasons: Strategically, ending federal work on local flood-control and rivers and harbors projects withdraws patronage from almost every member of Congress and threatens the power of a solid sectional coalition for the benefit of a constitutional principle and lower federal taxes. It would seem, on the record we examined, to be an unequal struggle, although this is the sort of estimate on which political science is almost useless.

The more solid reason why state and local responsibility for water resources development cannot be expected uniformly, however, is that each basin presents a unique situation. Not only are state capacities varied (this is true also in highway and education administration), but by its geographic reach and economic potential, each basin has its own degree of amenability to state development. How much the states can do, and through what instrumentality, is a product of all the variables in our hypotheses-and doubtless others, too. The philosophy that we can, on the basis of successful experience in one basin, "march on" to apply the policy or organization to the others is as arbitrary and sterile when applied to interstate compacts or federal departmental administration as it is when applied to valley authorities.

\footnotetext{
${ }^{87}$ Including Comm'N on Intergovernmental Relations, Report to the President 239-45 (1955).

${ }^{88}$ See Lepawsky, Water Resources and American Federalism, 44 AM. Pol. Scr. Rev. 639 (1950).
} 


\section{VII}

\section{Conclusion}

We have failed to find viable answers to the problems of governing our water resources, because we have been looking in the wrong places. We have looked to national departmentalization and executive organization, while the problem is basically one of public attention and interest. We have looked for assertions of policy, but the problem is one of discovering people's conscious needs. We have conceived of techniques as decisive and of the natural flow of water as embodying some human imperative, when its true human meaning is variety and diversity of potential. The water potentials which enlist human enterprise and decision over the years do not coincide, save by remote chance or by the most painstaking institutional arrangements, with states, cities, or the nation. The water potentials which move states, cities, and the nation immediately to act are fleeting and capricious and incapable of being harnessed economically, save by measures which assume long-term human enterprise. One alternative before us, therefore, is to continue to try to rationalize our national government and to make uniform devolutions to the states-although consent born of crisis will continue to thwart and misdirect those efforts. Or we can try to define and call into being communities of interest, finding a substantial and contributing part in water resources programs for the populations of the nation, the state, the basin, and the locality.

That alternative is not the same as that for which Mr. Lilienthal cited the auhority of Tocqueville. ${ }^{89}$ For to Tocqueville, the choice lay between autocratic central administration and local administration. ${ }^{90}$ It is only through high-quality and flexible national administration that, in the case of great interstate basins (as in the case of other complex national programs), an important sphere for local administration is found. But neither is our alternative that of political scientists who take for granted an existing national interest in improved water resources administration. We have fresh thinking to do.

${ }^{80}$ David E. Lilienthal, TVA: Densocracy on me March I63-64 (Pocket Books ed. 1945).

oo I Alexis de Tocqueville, Democracy in America 86-97 (Phillips Bradley ed. I945). 
